\title{
Comet assay and micronucleus test in circulating erythrocytes of Cyprinus carpio specimens exposed in situ to lake waters treated with disinfectants for potabilization
}

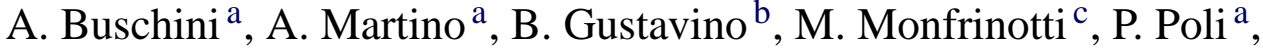 \\ C. Rossi ${ }^{\text {a }}$, M. Santoro ${ }^{b}$, A.J.M. Dörr ${ }^{\mathrm{d}}{ }^{\text {, M. Rizzoni }}{ }^{\mathrm{b}, *}$ \\ a Dipartimento di Genetica Antropologia Evoluzione, Università degli Studi di Parma, Parma, Italy \\ b Dipartimento di Biologia, Università degli Studi di Roma "Tor Vergata", via della Ricerca Scientifica s.n.c., Rome, Italy \\ ${ }^{\mathrm{c}}$ Laboratorio di Ecologia Sperimentale e Acquacoltura, Dipartimento di Biologia, Università degli Studi di Roma "Tor Vergata", Rome, Italy \\ d Dipartimento di Biologia Animale ed Ecologia, Università di Perugina, Perugina, Italy
}

Received 8 April 2003; received in revised form 11 July 2003; accepted 1 October 2003

\begin{abstract}
The detection of a possible genotoxic effect of surface water treated with disinfectants for potabilization is the aim of the present work. The Comet assay and the micronucleus test were applied in circulating erythrocytes of Cyprinus carpio. Young specimens $(20-30 \mathrm{~g})$ were exposed in experimental basins, built within the potabilization plant of Castiglione del Lago (Perugia, Italy). In this plant the water of the Trasimeno Lake is treated and disinfected for potabilization before it is distributed to the people in the net of drinkable water. A continuous flow of water at a constant rate was supplied to basins; the water was continuously treated at a constant concentration with one of the three tested disinfectants (sodium hypochlorite, peracetic acid and chloride dioxide), one control basin being supplied with untreated water. Three sampling campaigns were performed: October 2000, February 2001 and June 2001. Repeated blood samplings through intracardiac punctures allowed to follow the same fish populations after different exposure times: before introduction of the disinfectant, and 10 or 20 days afterwards. An additional blood sampling was performed $3 \mathrm{~h}$ after addition of the disinfectant in other, simultaneously exposed, fish populations. Genotoxic damage was shown in fish exposed to water disinfected with sodium hypochlorite and chloride dioxide. The Comet assay showed an immediate response, i.e. DNA damage that was induced directly in circulating erythrocytes, whereas micronuclei reached their highest frequencies at later sampling times, when a genotoxic damage in stem cells of the cephalic kidney is expressed in circulating erythrocytes. The quality of the untreated surface water seems to be the most important parameter for the long-term DNA damage in circulating erythrocytes.
\end{abstract}

(c) 2003 Elsevier B.V. All rights reserved.

Keywords: Water potabilization; Disinfectants; Micronuclei; Comet assay; Circulating erythrocytes; Cyprinus carpio

\footnotetext{
* Corresponding author. Tel.: +39-06-7259-4812; fax: +39-06-2023500.

E-mail address: rizzoni@uniroma2.it (M. Rizzoni).
}

\section{Introduction}

Chlorine as drinking water disinfectant may produce toxic by-products, such as haloalkenes, haloacetic acids, haloacetonitriles, haloketones and haloaldehydes, in particular if water is obtained from 
surface sources [1]. Water chlorination has been shown to give rise to formation of mutagenic/carcinogenic by-products which derive from reactions of chlorine with organic compounds (humic and fulvic acids) present in natural water [2-6]. Epidemiological studies generally support the correlation between consumption of chlorinated drinking water and an increased risk for cancer of the urinary and gastrointestinal tracts [7-9]; studies on bladder cancer provide further evidence for this correlation [6]; long-term carcinogenicity studies in rats supplied with sodium hypochlorite $(\mathrm{NaClO})$ in drinking water showed an increase in leukaemia in females [10]. Among disinfectants alternative to chlorine, chlorine dioxide $\left(\mathrm{ClO}_{2}\right)$ is widely used, while peracetic acid $\left(\mathrm{CH}_{3} \mathrm{COO}_{2} \mathrm{H}\right.$, PAA) deserves to be studied for its application in drinking water disinfection; PAA is a potent antimicrobial agent with many applications in hospitals, laboratories and factories [11-13]. Disinfection of lake and river water for potabilization with PAA produced only carboxylic acids, not recognized as mutagenic, and resulted in a very low level of genotoxicity [14].

A useful approach to detect mutagenicity in water is the in vivo treatment/in situ exposure of plants, e.g. Zea mays [15], Vicia faba [16], Allium cepa [17] and Tradescantia spp. $[18,19]$ or aquatic animals, e.g. newts [20-22], polychaetes [23] or molluscs [24-26]. For example, sodium hypochlorite by-products with humic substances increased the micronucleus frequency in erythrocytes of newt larvae [27]. The micronucleus test in circulating erythrocytes of fish has been widely employed for both in situ exposure to environmental waters [28-32] and laboratory treatments in vivo [33-37]; in particular this test has been employed in Cyprinus carpio [38-40]. The micronucleus test is a very sensitive and useful method that can detect both clastogenic and aneugenic activity (for a review, see $[41,42]$ ). The test appears to be a promising tool for the monitoring of drinking water.

An additional sensitive indicator of genetic damage is DNA strand breakage, which can be detected by the alkaline single-cell gel electrophoresis assay (Comet assay). This assay has been applied in aquatic environments both on vertebrate and invertebrate organisms [43-46]. In particular, in vivo data on fish were obtained with redbreast sunfish (Lepomis auritus), hard head cat fish (Anus felis), bullhead (Ameirurus nebulosus) and carp (C. carpio) $[45,47]$. Furthermore, the
German Federal Environmental Agency proposes the Comet assay as a useful test in a graduated testing battery for a reliable detection of genotoxicity of surface waters [48].

The experiments described in the present paper are part of a multidisciplinary research project with the aim to assess the presence of genotoxic activity in surface drinking water treated with different disinfectants ( $\left.\mathrm{NaClO}, \mathrm{ClO}_{2}, \mathrm{PAA}\right)$. For this purposes a pilot plant was built within the potabilization plant of Castiglione del Lago (Perugia, Italy), where the water of lake Trasimeno (l.w.) is disinfected for potabilization. In the pilot plant an integrated approach was taken, including chemical analyses, microbiological tests, and in vitro and in vivo genotoxicity tests (see [49]).

In this paper we report data on the micronucleus test and Comet assay in circulating erythrocytes of $C$. carpio exposed in situ to water containing disinfectants. Fish were exposed for 20 days in basins within the pilot plant; blood samples were taken at different times from the same specimens, in order to study the time course of the mutagenic end points in the same fish populations. Blood samples were also taken $3 \mathrm{~h}$ after the start of the exposure from different specimens. The experiments took place in October 2000 and February and June 2001.

\section{Materials and methods}

\subsection{Lake water}

Lake Trasimeno, a mesotrophic limnic environment, was chosen as a site with surface water with a high concentration of total organic carbon (TOC) and bromide, both possible precursors of mutagenic disinfection by-products.

\subsection{Pilot plant-(see [49])}

The following functional units were the main components of the pilot plant:

(1) a lake water capturing system;

(2) a sedimentation system (Corby 10, FZ Fantoni, Bedizzole, Italy), with two $1-\mathrm{m}^{3}$ reservoirs to clarify the water;

(3) a filtration system (a 50- $\mu \mathrm{m}$ pore size inox stainless steel filter followed by a $25-\mu \mathrm{m}$ pore size filter 
cloth) to remove suspended particles (Fluxa Filtri S.p.A., Milan, Italy);

(4) a pumping system in which sulphuric acid is added to neutralize the water to $\mathrm{pH} 7$;

(5) one main pipeline divided into four secondary ones that supply filtered water (flux: $3001 / \mathrm{h}$ ) to four 300-1 stainless basins (contact basins);

(6) four contact basins, one with untreated water and three in which water was in contact and interacted with the disinfectants used in the experiments;

(7) four $1-\mathrm{m}^{3}$ stainless steel basins (exposure basins) used for in situ exposure of bioindicators (fish, molluscs and plants), which received the water flowing from the contact basins.

\subsection{Disinfectants}

(1) Sodium hypochlorite $(\mathrm{NaClO})$ (Solvay S.p.A., Rosignano, LI, Italy): supplied as a 14.5-15.5\% solution through a membrane pump.

(2) Chlorine dioxide $\left(\mathrm{ClO}_{2}\right)$, produced in loco directly from an $8 \% \mathrm{NaClO}_{2}$ solution and $10 \% \mathrm{HCl}$ through an automatic generator (Tecme S.r.l., Gardolo di Trento, TN, Italy).

(4) Peracetic acid $\left(\mathrm{CH}_{3} \mathrm{COO}_{2} \mathrm{H}\right)$ (Promox S.r.l. Leggiuno, VA, Italy): supplied as a $15 \%$ solution through a membrane pump.

Disinfectant concentrations were chosen on the basis of chlorine demand of the water, after preliminary laboratory experiments. Free disinfectant residues in disinfected water were monitored twice a day during the exposure of 20 days for a total of 40 determinations with a field photometer (DR 2000, Hach); total and free chlorine concentrations were determined with a standard $N, N$-diethyl- $p$-phenylene diamine (DPD) method; $\mathrm{ClO}_{2}$ concentration was determined with phenol red and residual PAA was measured with a total DPD reaction, after treatment with catalase and a potassium iodide reaction. On this basis the concentrations of the disinfectants were adjusted twice a day to maintain the free residue concentration $<0.2 \mathrm{mg} / \mathrm{l}$, in order to avoid direct toxicity to fishes and mussels. The mean $( \pm$ S.D. $)$ of the disinfectant concentrations added during the exposure were:

- October 2000: $1.24 \pm 0.19 \mathrm{mg} / \mathrm{l}$ of $\mathrm{NaClO}, 1.64 \pm$ $0.21 \mathrm{mg} / \mathrm{l}$ of $\mathrm{ClO}_{2}$ and $1.00 \pm 0.19 \mathrm{mg} / \mathrm{l}$ of PAA;
- February 2001: $0.71 \pm 0.06 \mathrm{mg} / \mathrm{l}$ of $\mathrm{NaClO}, 1.63 \pm$ $0.22 \mathrm{mg} / \mathrm{l}$ of $\mathrm{ClO}_{2}$ and $0.61+0.04 \mathrm{mg} / \mathrm{l}$ of PAA;

- June 2001: $0.55 \pm 0.09 \mathrm{mg} / \mathrm{l}$ of $\mathrm{NaClO}, 1.84 \pm$ $0.05 \mathrm{mg} / \mathrm{l}$ of $\mathrm{ClO}_{2}$ and $0.90 \pm 0.05 \mathrm{mg} / \mathrm{l}$ of PAA.

\subsection{Fish exposure and blood sampling}

The study consisted of 20-day long experiments and was carried out in different seasons (October 2000, February 2001 and June 2001) in order to assess the effects of disinfection in different physical and chemical conditions of the lake water. Young specimens of C. carpio (age: $<1$ year; weight: 20-30 g), were supplied by the 'Centro Ittiogenico di Sant'Arcangelo' (Perugia, Italy). Specimens were introduced in each basin 20 days before the start of the exposure, to allow acclimatization. Blood samples were taken through intracardiac puncture with heparinized syringes from each fish (eight specimens for Comet assay [50] and 10 for MN, eight of which were also employed for the Comet assay), anaesthetized with $0.1 \mathrm{~g} / \mathrm{l}$ of MS-222 Finquel (SCUBLA S.n.c.). After a 5-min recovery period in filtered lake water, fishes were replaced in their own basin. The first sampling was performed immediately before the disinfectants were supplied to the water in the contact basins, for both micronucleus test and Comet assay. Different sampling times were chosen after the start of exposure: $3 \mathrm{~h}$ for the Comet assay, 10 days for the micronucleus test and 20 days for both micronucleus test and Comet assay. Samples were repeatedly taken from the same fish specimens of each basin, except for the $3 \mathrm{~h}$ sampling, due to the fact that successive cardiac puncture must be made with an interval of at least $24 \mathrm{~h}$ (preliminary experiments, unpublished data). Some specimens died before the end of the exposure period. Therefore, blood samples were taken from nine specimens only at 10 and 20 days in February 2001 in the basins containing $\mathrm{ClO}_{2}$-disinfected lake water, at 20 days in February 2001 in the basins containing $\mathrm{NaClO}$-disinfected lake water, and at 20 days in June 2001 in the basins containing untreated lake water.

\subsection{Monitoring of physical-chemical variables}

The physicochemical variables were examined in the exposure basins at the start of the experiment and at the 10- and 20-day sampling times. Temperature, 
oxygen concentration and $\mathrm{pH}$ were measured in situ using a Multiline P4 WTW probe. The following chemical analyses were performed on water, after filtration (glass fibre filters Whatman GF/F): nitrite (colorimetry, diazotization method), nitrate (colorimetry, cadmium reduction method), ammonium (colorimetry, indophenol blue), and phosphorus (colorimetry, ascorbic acid method) [50].

\subsection{Micronucleus test}

Blood smears were done immediately after sampling, fixed with absolute ethanol for $20 \mathrm{~min}$, stained with Feulgen and mounted with dissolved polystyrene in xylene (DPX; Fluka). For each specimen, 25000 erythrocytes were scored at $1000 \times$ magnification. After blind scoring, statistical analysis was carried out for each experiment with non-parametric tests (Mann-Whitney test after a Kruskal-Wallis non-parametric ANOVA). Comparisons were made between fish populations before the start of the exposure to disinfected water and within the same population, exposed to the same disinfected water, before exposure and at the different exposure times: 10 and 20 days.

\subsection{Comet assay}

The single-cell gel electrophoresis assay was basically performed according to [51,52]. Freshly withdrawn cells $(20 \mu \mathrm{l})$ were added to $80 \mu \mathrm{l}$ of $0.65 \%$ low melting agarose (LMA) in PBS and then transferred onto degreased microscope slides previously dipped in $1 \%$ normal melting agarose (NMA) for the first layer. The agarose was allowed to set for $5 \mathrm{~min}$ at $4{ }^{\circ} \mathrm{C}$ before addition of a final layer of LMA. After agarose solidification, the slides were placed in lysing solution (2.5 M NaCl, $100 \mathrm{mM} \mathrm{Na} 2$ EDTA, $10 \mathrm{mM}$ Tris-HCl, $1 \%$ Triton X-100 and 10\% DMSO, pH 10) in a Coplin jar at $4{ }^{\circ} \mathrm{C}$ overnight in the dark.

Alkaline DNA-unwinding was carried out in a gel electrophoresis chamber containing a freshly prepared buffer ( $1 \mathrm{mM} \mathrm{Na}_{2}$ EDTA, $300 \mathrm{mM} \mathrm{NaOH}$, pH 13) for $10 \mathrm{~min}$ and electrophoresis was performed in the same buffer for $20 \mathrm{~min}$ at $0.78 \mathrm{~V} \mathrm{~cm}^{-1}$ and $300 \mathrm{~mA}$. DNA unwinding and electrophoresis were performed in an ice-water bath. Once the electrophoresis had been carried out, the slides were washed in a neutralisation buffer (0.4 M Tris-HCl, pH 7.5). All the steps described above were performed under yellow light to minimise additional UV-induced DNA damage.

After staining with $100 \mu \mathrm{l}$ ethidium bromide $(10 \mu \mathrm{l} / \mathrm{ml})$, observations were made under a fluorescence microscope (Leitz Dialux 20) equipped with an excitation filter BP $515-560 \mathrm{~nm}$ and a barrier filter LP $580 \mathrm{~nm}$, using an image-analysis system (Cometa Release ${ }^{\circledR} 2.1$ Sarin, Florence, Italy).

For each sample, coded and evaluated blind, 100 cells were analysed; clouds of DNA fragments were registered as number and were not considered for the analysis. The relationship between tail moment (TM) and Comet length was examined by simple linear regression $(R=0.967 ; P<0.001)$. The Comet parameter TM was chosen to represent the data on genotoxic effects.

Statistical analysis was performed by SPSS 10 for each experiment on the mean of medians of TM values, which is normally distributed, with Student's $t$-test after ANOVA. Comparisons were made, for long-time exposure (20 days), within the same population, exposed to the same disinfected water, at different exposure times (before start of exposure and 20 days after); comparisons were made for short-time exposures $(3 \mathrm{~h})$, between each population sampled after $3 \mathrm{~h}$ from the start of disinfection and the whole population (32 specimens) sampled at time 0 , considered as a control $\left(\mathrm{C}_{0}\right)$.

\section{Results}

\subsection{Physical-chemical parameters}

The data are presented in Table 1 . The $\mathrm{pH}$ of the water did not show significant variation (7.3-7.8). The temperature showed the typical seasonal fluctuation of Central Italy (October 2000: $16-17^{\circ} \mathrm{C}$; February 2001: $5-10^{\circ} \mathrm{C}$; June $2001: 22-24^{\circ} \mathrm{C}$ ). An inverse pattern was seen for the oxygen concentration, which is due partially to a different solubility of oxygen in water at different temperatures. Nitrates reached their highest concentration values during February 2001, while phosphates reached their highest concentration values in June 2001 and the lowest in February 2001. Nutrient concentrations were always compatible with the rearing demand; critical, sub-toxic values were shown 
Table 1

Mean values and standard deviations of physico-chemical parameters in the basins during the study period

\begin{tabular}{|c|c|c|c|c|c|c|c|c|}
\hline \multirow[t]{2}{*}{ Sampling } & \multirow[t]{2}{*}{ Exposure } & \multirow[t]{2}{*}{$\mathrm{pH}$} & \multicolumn{2}{|l|}{$\mathrm{O}_{2}$} & \multirow[t]{2}{*}{$\mathrm{N}-\mathrm{NO}_{2}(\mathrm{ppb})$} & \multirow[t]{2}{*}{$\mathrm{N}-\mathrm{NO}_{3}(\mathrm{ppm})$} & \multirow[t]{2}{*}{$\mathrm{NH}_{4}^{+}(\mathrm{ppb})$} & \multirow[t]{2}{*}{$\mathrm{PO}_{2}{ }^{3-}(\mathrm{ppb})$} \\
\hline & & & ppm & (\% sat.) & & & & \\
\hline October $2000\left(16.8 \pm 0.5^{\circ} \mathrm{C}\right)$ & $\begin{array}{l}\text { Untreated lake water } \\
\text { l.w. }+\mathrm{CH}_{3} \mathrm{COO}_{2} \mathrm{H} \\
\text { 1.w. }+\mathrm{NaClO} \\
\text { l.w. }+\mathrm{ClO}_{2}\end{array}$ & $\begin{array}{l}7.5 \pm 0.2 \\
7.5 \pm 0.0 \\
7.5 \pm 0.0 \\
7.4 \pm 0.1\end{array}$ & $\begin{array}{l}7.6 \pm 0.3^{\mathrm{a}}(1) \\
7.4 \pm 0.3 \\
7.2 \pm 0.4 \\
7.1 \pm 0.1^{\mathrm{a}}\end{array}$ & $\begin{array}{l}80.35 \pm 3.7^{\mathrm{a}}(2) \\
77.9 \pm 4.6 \\
75.8 \pm 5.6 \\
74.5 \pm 0.8^{\mathrm{a}}(5)\end{array}$ & $\begin{array}{l}4.3 \pm 0.6 \\
4 \pm 1.0 \\
3 \pm 1.7 \\
3.7 \pm 2.3\end{array}$ & $\begin{array}{l}1.03 \pm 0.4 \\
0.83 \pm 0.2 \\
0.93 \pm 0.1 \\
0.83 \pm 0.2\end{array}$ & $\begin{array}{l}80.0 \pm 0.0^{\mathrm{a}}(3) \\
53.0 \pm 5.8 \\
76.7 \pm 32.1 \\
70.0 \pm 28.3^{\mathrm{a}}(6)\end{array}$ & $\begin{array}{l}200 \pm 120.0 \\
137 \pm 5.7 \\
107 \pm 15.3 \\
137 \pm 47.3\end{array}$ \\
\hline February $2001\left(8.1 \pm 2.2^{\circ} \mathrm{C}\right)$ & $\begin{array}{l}\text { Untreated lake water } \\
\text { l.w. }+\mathrm{CH}_{3} \mathrm{COO}_{2} \mathrm{H} \\
\text { l.w. }+\mathrm{NaClO} \\
\text { l.w. }+\mathrm{ClO}_{2}\end{array}$ & $\begin{array}{l}7.8 \pm 0.1 \\
7.7 \pm 0.1 \\
7.7 \pm 0.1 \\
7.6 \pm 0.1\end{array}$ & $\begin{array}{l}10.5 \pm 0.8 \\
10.9 \pm 0.7 \\
10.8 \pm 0.7 \\
10.6 \pm 0.1\end{array}$ & $\begin{array}{l}90.1 \pm 2.5 \\
94.0 \pm 1.1 \\
93.4 \pm 1.6 \\
93.7 \pm 3.2\end{array}$ & $\begin{array}{l}3.3 \pm 0.8 \\
3.7 \pm 1.5 \\
5.3 \pm 1.2 \\
4.7 \pm 0.6\end{array}$ & $\begin{array}{l}1.07 \pm 0.1 \\
1.2 \pm 0.0 \\
1.4 \pm 0.1 \\
1.2 \pm 0.1\end{array}$ & $\begin{array}{l}66.7 \pm 5.8 \\
50.0 \pm 0.0 \\
76.7 \pm 40.4 \\
43.3 \pm 5.8\end{array}$ & $\begin{array}{l}10 \pm 0.0 \\
17 \pm 1.2 \\
17 \pm 1.2 \\
20 \pm 10.0\end{array}$ \\
\hline June $2001\left(23.6 \pm 1.2^{\circ} \mathrm{C}\right)$ & $\begin{array}{l}\text { Untreated lake water } \\
\text { 1.w. }+\mathrm{CH}_{3} \mathrm{COO}_{2} \mathrm{H} \\
\text { l.w. }+\mathrm{NaClO} \\
\text { l.w. }+\mathrm{ClO}_{2}\end{array}$ & $\begin{array}{l}7.4 \pm 0.1 \\
7.3 \pm 0.1 \\
7.3 \pm 0.1 \\
7.3 \pm 0.1\end{array}$ & $\begin{array}{l}5.6 \pm 1.0 \\
6.0 \pm 1.0 \\
6.2 \pm 0.6 \\
6.6 \pm 0.6\end{array}$ & $\begin{array}{l}67.3 \pm 10.0 \\
74.2 \pm 7.5 \\
74.9 \pm 7.5 \\
79.6 \pm 7.0\end{array}$ & $\begin{array}{l}6 \pm 2.6 \\
5.7 \pm 3.8 \\
4.7 \pm 1.2 \\
4.3 \pm 1.2\end{array}$ & $\begin{array}{l}0.67 \pm 0.1 \\
0.57 \pm 0.2 \\
0.97 \pm 0.4 \\
0.6 \pm 0.1\end{array}$ & $\begin{array}{l}66.7 \pm 20.8 \\
60.0 \pm 26.5 \\
66.7 \pm 20.8 \\
63.3 \pm 11.6\end{array}$ & $\begin{array}{l}167 \pm 66.6 \\
137 \pm 55.1 \\
223 \pm 60.3 \\
163 \pm 90.7\end{array}$ \\
\hline
\end{tabular}

Measurements were performed at the blood sampling times, during a continuous exposure to the water of lake Trasimeno lake treated with different disinfectants $\left(\mathrm{CH}_{3} \mathrm{COO}_{2} \mathrm{H}\right.$ $\mathrm{NaClO}$ and $\mathrm{ClO}_{2}$ ). Concentrations of chemicals are expressed as ppm, unless otherwise specified.

${ }^{a}$ Computations were made excluding critical values due to overcrowding, which were shown before the start of exposure during the experiment in October 2000 , when all fish were stored in the basin for untreated lake water and for $\mathrm{ClO}_{2}$-disinfected lake water; critical values were the following- $\mathrm{O}_{2}(\mathrm{ppm}):(1)=2.68,(4)=1.03 ; \mathrm{O}_{2}(\%$ sat): (2) $=27.9,(5)=11.5 ; \mathrm{NH}_{4}{ }^{+}(\mathrm{ppb}):(3)=170,(6)=380$. 
Table 2

Average micronucleus frequency per 25000 red blood cells \pm S.E.

\begin{tabular}{|c|c|c|c|c|c|}
\hline \multirow[t]{2}{*}{ Month and year } & \multirow[t]{2}{*}{ Sampling time (days) } & \multicolumn{4}{|l|}{ Exposure } \\
\hline & & Untreated lake water & 1.w. $+\mathrm{CH}_{3} \mathrm{COO}_{2} \mathrm{H}$ & 1.w. $+\mathrm{NaClO}$ & 1.w. $+\mathrm{ClO}_{2}$ \\
\hline \multirow[t]{3}{*}{ October 2000} & 0 & $0.4 \pm 0.16$ & $0.7 \pm 0.26$ & $0.6 \pm 0.22$ & $0.5 \pm 0.17$ \\
\hline & 10 & $0.5 \pm 0.17$ & $0.6 \pm 0.22$ & $0.9 \pm 0.31$ & $0.7 \pm 0.21$ \\
\hline & 20 & $0.5 \pm 0.22$ & $0.8 \pm 0.25$ & $2.5 \pm 0.50^{* *}$ & $1.7 \pm 0.42^{* *}$ \\
\hline \multirow[t]{3}{*}{ February 2001} & 0 & $0.3 \pm 0.15$ & $0.2 \pm 0.13$ & $0.2 \pm 0.13$ & $0.3 \pm 0.21$ \\
\hline & 10 & $0.4 \pm 0.16$ & $0.3 \pm 0.15$ & $0.7 \pm 0.21$ & $0.7 \pm 0.33$ \\
\hline & 20 & $0.3 \pm 0.1$ & $0.6 \pm 0.22$ & $1.3 \pm 0.33^{*}$ & $1.4 \pm 0.47$ \\
\hline \multirow[t]{3}{*}{ June 2001} & 0 & $0.5 \pm 0.23$ & $0.4 \pm 0.16$ & $0.5 \pm 0.22$ & $0.3 \pm 0.15$ \\
\hline & 10 & $0.4 \pm 0.16$ & $0.7 \pm 0.26$ & $0.8 \pm 0.25$ & $0.9 \pm 0.23$ \\
\hline & 20 & $0.5 \pm 0.24$ & $1 \pm 0.33$ & $2.5 \pm 0.50^{* *}$ & $1.8 \pm 0.41^{* *}$ \\
\hline
\end{tabular}

Observations were made on 25000 circulating erythrocytes per blood sample in specimens of $C$. carpio following a continuous exposure to the water of lake Trasimeno treated with different disinfectants $\left(\mathrm{CH}_{3} \mathrm{COO}_{2} \mathrm{H}, \mathrm{NaClO}\right.$ and $\left.\mathrm{ClO}_{2}\right)$. Blood samples were taken immediately before exposure and at different times (10 and 20 days) after the start of exposure in the same specimens; untreated lake water was used as a control. Experiments were performed in different seasons (October 2000, February 2001 and June 2001). Statistical analysis was performed using Mann-Whitney test after a Kruskal-Wallis non-parametric ANOVA, by which micronucleus frequencies after 10 or 20 exposure days were compared, for each disinfectant treatment, to that found before exposure (day 0), in the same fish population.

$$
\begin{aligned}
& { }^{*} P<0.05 . \\
& { }^{* *} P<0.01 \text {. }
\end{aligned}
$$

for oxygen and ammonium concentrations before the start of exposures, in basins for untreated lake water and for $\mathrm{ClO}_{2}$-disinfected lake water, due to occasional fish overcrowding in October 2000. ${ }^{1}$

\subsection{Micronucleus test}

Data on micronuclei are given in Table 2. The main results are the following:

(1) There is no significant difference in any experiment in micronucleus frequency among fish populations in the four basins at time 0 , that is immediately before the beginning of exposure to disinfected water; it testifies a very good homogeneity in the starting conditions.

(2) For all disinfectants there is an increase in micronucleus frequency within the same fish populations with increasing exposure times; nevertheless, this increase reaches statistical significance in some cases only.

(3) There is a significant increase in micronucleus frequency in fish populations exposed to $\mathrm{NaClO}$ disinfected water in all the experiments and to

\footnotetext{
${ }^{1}$ All fish were stored in these two basins before the start of exposure at October 2000.
}

$\mathrm{ClO}_{2}$-disinfected water in the experiments of October 2000 and June 2001; a significant increase compared with the micronucleus frequency at $t=$ 0 (i.e. before exposure) is reached at $t=20$, while the difference is not yet significant at $t=10$.

\subsection{Comet assay}

The main results (Table 3) are the following:

(1) No significant differences (ANOVA) were found within the same experiment among the fish populations in the four basins at time 0 .

(2) DNA migration of populations samples at $t=0$ in the June 2001 sampling was significantly higher than in the October 2000 and February 2001 samplings $(P<0.001)$.

(3) The comparison among the 3-h samples and data collected from all the specimens sampled at time 0 (control, $\mathrm{C}_{0}$ ) shows a significant DNA migration increase for the basins with chlorinated disinfectant in October $2000(P<0.001 \mathrm{NaClO} ; P<$ $\left.0.01 \mathrm{ClO}_{2}\right)$ and February $2001(P<0.01 \mathrm{NaClO}$ and $\mathrm{ClO}_{2}$ ).

(4) The blood re-sampling in the same fish populations after a 20 days exposure shows: (i) October 2000: DNA migration was not affected by type 
Table 3

Average median tail moment (TM) \pm S.D. in 100 circulating erythrocytes per specimen of $C$. carpio following continuous exposure to the water of lake Trasimeno treated with different disinfectants $\left(\mathrm{CH}_{3} \mathrm{COO}_{2} \mathrm{H}, \mathrm{NaClO}\right.$ and $\left.\mathrm{ClO}_{2}\right)$ in different seasons (October 2000, February 2001 and June 2001)

\begin{tabular}{|c|c|c|c|c|c|}
\hline Exposure & Sampling time & Untreated lake water & 1.w. $+\mathrm{CH}_{3} \mathrm{COO}_{2} \mathrm{H}$ & 1.w. $+\mathrm{NaClO}$ & 1.w. $+\mathrm{ClO}_{2}$ \\
\hline \multicolumn{6}{|c|}{ October 2000} \\
\hline \multirow[t]{2}{*}{ Short } & $\mathrm{C}_{0}$ & $14.30 \pm 3.95$ & $14.30 \pm 3.95$ & $14.30 \pm 3.95$ & $14.30 \pm 3.95$ \\
\hline & $3 \mathrm{~h}$ & $16.16 \pm 2.05$ & $15.62 \pm 4.13$ & $22.76 \pm 2.66^{* * *}$ & $19.55 \pm 4.95^{* *}$ \\
\hline \multirow[t]{2}{*}{ Long } & 0 & $12.58 \pm 1.90$ & $15.87 \pm 4.84$ & $14.79 \pm 5.01$ & $13.95 \pm 3.24$ \\
\hline & 20 days & $12.59 \pm 4.68$ & $16.43 \pm 2.67$ & $15.53 \pm 3.66$ & $12.18 \pm 3.21$ \\
\hline \multicolumn{6}{|c|}{ February 2001} \\
\hline \multirow[t]{2}{*}{ Short } & $\mathrm{C}_{0}$ & $15.09 \pm 5.19$ & $15.09 \pm 5.19$ & $15.09 \pm 5.19$ & $15.09 \pm 5.19$ \\
\hline & $3 \mathrm{~h}$ & $19.09 \pm 5.78$ & $19.18 \pm 4.76$ & $22.27 \pm 4.72^{* *}$ & $23.09 \pm 3.38^{* *}$ \\
\hline \multirow[t]{2}{*}{ Long } & 0 & $13.56 \pm 3.15$ & $12.99 \pm 4.30$ & $14.42 \pm 8.09$ & $17.57 \pm 3.56$ \\
\hline & 20 days & $24.98 \pm 9.30^{*}$ & $30.48 \pm 4.43^{* * *}$ & $28.17 \pm 7.92^{* *}$ & $21.33 \pm 5.81$ \\
\hline \multicolumn{6}{|l|}{ June 2001} \\
\hline \multirow[t]{2}{*}{ Short } & $\mathrm{C}_{0}$ & $34.20 \pm 11.97$ & $34.20 \pm 11.97$ & $34.20 \pm 11.97$ & $34.20 \pm 11.97$ \\
\hline & $3 \mathrm{~h}$ & $37.24 \pm 10.29$ & $36.67 \pm 11.02$ & $30.62 \pm 6.04$ & $39.53 \pm 10.58$ \\
\hline \multirow[t]{2}{*}{ Long } & 0 & $38.21 \pm 8.48$ & $27.12 \pm 12.19$ & $37.12 \pm 12.29$ & $34.38 \pm 13.32$ \\
\hline & 20 days & $21.82 \pm 7.45^{* * *}$ & $9.60 \pm 1.81^{* *}$ & $13.17 \pm 5.23^{* *}$ & $22.61 \pm 7.94^{*}$ \\
\hline
\end{tabular}

Blood samples were taken immediately before exposure and 20 days after the start of exposure, in the same specimens; blood samples were taken $3 \mathrm{~h}$ after the start in separate fish populations. Statistical analysis was performed using Student's $t$-test after ANOVA for the Comet assay (SCGE) by which DNA migration in the specimens exposed for 20 days was compared to that found before exposure in the same fish population (unexposed sample); DNA migration of the populations exposed for $3 \mathrm{~h}$ was compared to the mean values of DNA migration in the unexposed samples $\left(\mathrm{C}_{0}\right)$.

${ }^{*} P<0.05$.

** $P<0.01$.

*** $P<0.001$.

of disinfectant or exposure time; (ii) February 2001: a significant increase in DNA migration compared with the $t=0$ sampling was observed in basins with untreated water, PAA, and NaClO $(P<0.001)$; (iii) June 2001: a significant decrease of DNA migration was shown in all situations $(P<0.05$ for untreated water; $P<0.01$ for PAA and $\mathrm{ClO}_{2} ; P<0.001$ for $\mathrm{NaClO}$ ).

\section{Discussion}

The micronucleus test and the Comet assay are sensitive tools for an effective evaluation of field genotoxicity biomarkers. The Comet assay can detect directly DNA strand breaks, which may be induced very early after exposure to genotoxins. Micronuclei are the result of chromosome breaks (or mitotic anomalies) that require necessarily a passage through mitosis to be recognisable. Furthermore, while the Comet assay detects DNA breaks directly in circulating erythrocytes of the fish used in this study, micronuclei reveal chromosome breaks or mitotic anomalies that occur in stem cells in the cephalic kidney, from which circulating erythrocytes, eventually micronucleated, are released very slowly (a complete turnover requires at least 100 days).

The time course of micronucleus induction recorded in the present experiments is in good agreement both with data from laboratory treatments in the same [40] and other species [35] and during in situ exposure [32]. It can be explained on the basis of the time required for the turnover of red blood cells in fish. The lack of variation among the micronucleus frequencies at the start of the exposures and the regularity of their change over time suggest that they depend mainly on the presence of genotoxins rather than other environmental factors. Therefore, even if the frequency of micronuclei is very low in this system and a very large cell sample is required, this test showed to be reliable. In particular the present protocol, which allowed us to follow the same fish population over time, could avoid 
the inter-individual variation in the response to genotoxic compounds, which plays a role when different individuals are sampled at different times.

The variation in DNA migration detected by the Comet assay shows a strong seasonal influence both in terms of baseline level and sensitivity towards the treatments, in agreement with our previous studies in aquatic organisms [53]. The primary DNA damage, before the induction of the repair system, is clearly visible after $3 \mathrm{~h}$ exposure as an increase in DNA migration in the blood samples collected from the fish populations maintained in water treated with $\mathrm{NaClO}$ or $\mathrm{ClO}_{2}$ in October 2000 and in February 2001. On the other hand, after 20 days of exposure the response of the fish seems to be modulated by the environmental seasonal differences more than by the disinfectants or disinfection by-products. An exposure of 20 days seems to be too long to detect DNA primary damage induced by disinfection processes; in this case, temperature variations and seasonal variations in pollutant content of the lake water could be the major confounding factors. Xenobiotic-metabolising enzymes are known to be strongly modulated, in fish, in response to environmental conditions such as temperature, stress, diet, reproductive activity and presence of pollutants [54,55]. Water temperature could alter the baseline of DNA damage detected by the Comet assay as reported by other authors [56]. Acclimation response that involves the regulation of gene expression [57] is considered to be markedly significant for eurythermal fish such as carp, which can survive under a wide temperature range from near zero to over $30^{\circ} \mathrm{C}$. In carp, while low environmental temperatures induce a lower RNA trasduction activity [58], increasing temperatures directly stimulate the protein synthesis [59]. Repair mechanisms could also be increased with a consequent large number of repair-intermediates, i.e. DNA strand breaks. Hyperthermia was shown to be able to modulate DNA repair processes, with a shortening of the time required for DNA repair, as assessed by the Comet assay [60]. In this context, the increment of DNA baseline migration in June 2001 could reflect a faster metabolism in relation to the higher temperature, which could have masked the effect of the chlorinated disinfectants detected in the other seasons. The acclimation processes could also be modulated by the different amounts of pollutants: genotoxic compounds present in the water could increase the baseline DNA damage as suggested by the data obtained in February 2001 after a long-time exposure to untreated lake water.

A correspondence between short-term DNA damage, as detected by the Comet assay and aneugenic/clastogenic effects, as detected by the MN test in different fish populations was found for chlorinated disinfectants during the October 2000 and February 2001 campaigns. A clear correlation between long-term DNA damage and $\mathrm{MN}$ induction in the same specimens was not found, confirming the results of previous works on aquatic organisms [61] and human biomonitoring studies [62]. However, direct effects on DNA, detected in the Comet assay, represent an independent and sensitive end-point to assess a synergistic DNA-damaging potential of mixtures containing compounds producing repairable DNA breakage or alkali-labile sites [63].

Chlorinated disinfectants, i.e. $\mathrm{ClO}_{2}$ and $\mathrm{NaClO}$, seem to represent the major source of clastogenic/ aneugenic by-products following superficial water disinfection for potabilization, as assessed by the $\mathrm{MN}$ assay (October 2000 and June 2001, after 20-day exposures) and by the Comet assay, after 3-h exposures (October 2000 and February 2001) even if not in the same fish populations. These results are in agreement with the possible formation of genotoxic compounds, such as adsorbable organic halogens (AOX), after treatment of water with chlorinated disinfectants as shown by data on the production of trihalomethanes and AOX, detected in the same sampling campaigns (October 2000, February 2001 and June 2001) in the pilot plant at the beginning of the exposure [64].

With respect to the results of other mutagenicity tests performed with other systems in the same sampling campaigns (October 2000, February 2001 and June 2001) in the pilot plant, there is a good correspondence with data on mutagenicity in plants (Tradescantia spp., A. cepa and V. faba), which showed the strongest mutagenic effect in the temperate-warm seasons following exposure to $\mathrm{NaClO}-$ and $\mathrm{ClO}_{2-}$ disinfected waters [64].

\section{Acknowledgements}

Supported by the Italian Ministry of University and Research (MURST 1999). Many thanks are due to 
Centro Ittiogenico del Lago Trasimeno, in particular to Dr. Mauro Natali and Mr. Mario Panico, who kindly supplied and reared fish necessary for the research. We are grateful to the MURST Research Group:

- S. Monarca, C. Zani, A. Alberti, D. Feretti, and I. Zerbini, Hygiene Section, Department of Experimental and Applied Medicine, University of Brescia;

- Licia Guzzella, IRSA-CNR, Brugherio (MI);

- Laura Marabini and Enzo Chiesara, Department of Pharmacology, University of Milan;

- Giorgio Cantelli-Forti, Moreno Paolini, Patrizia Hrelia and Francesca Maffei, Department of Pharmacology, University of Bologna;

- Maria Illuminata Taticchi, Luciana Mantilacci and Concetta Elia, Department of Animal Biology and Ecology, University of Perugia;

- Claudia Bolognesi, National Institute on Cancer Research, Genoa;

- Augusto Morosi, Donatella Bartoli, Elisabetta Ciccarelli and Margherita di Brizio, ARPA Umbria, Perugia;

- Susan Richardson and Al Thurston, US Environmental Protection Agency, Athens, GA, USA.

\section{References}

[1] World Health Organization, Revision of the WHO Guidelines for Drinking Water Quality, World Health Organization, Geneva, Switzerland, 1996.

[2] J.J. Rook, Formation of haloforms during chlorination of natural waters, J. Water Treat. Examin. 23 (1974) 234-243.

[3] J.J. Rook, Chlorination reactions of fulvic acid in natural water, Environ. Sci. Technol. 11 (1977) 478-482.

[4] J.R. Meier, H.P. Ringhand, W.E. Coleman, Mutagenic byproducts from chlorination of humic acid, Environ. Health Perspect. 69 (1986) 101-107.

[5] S.C. Agarwal, J. Neton, Mutagenicity and alkylating activity of the aqueous chlorination products of humic acid and their molecular weight fractions, Sci. Total Environ. 79 (1989) 6983.

[6] K.T. Cantor, Drinking water and cancer, Cancer Causes Contr. 8 (1997) 292-308.

[7] T.J. Doyle, W. Zheng, J.R. Cerhan, C.P. Hong, T.A. Sellers, L.H. Kushi, A.R. Folsom, The association of drinking water source and chlorination by-products with cancer incidence among postmenopausal women in Iowa: a prospective cohort study, Am. J. Pub. Health 87 (1997) 1168-1176.

[8] M. Koivusalo, E. Pukkala, T. Vartiainen, Drinking water chlorination and cancer-a historical cohort study in Finland, Cancer Causes Contr. 8 (1997) 192-200.
[9] X. Tao, H. Zhu, G.M. Matanoski, Mutagenic drinking water and risk of male esophageal cancer: a population-based casecontrol study, Am. J. Epidemiol. 150 (1999) 443-451.

[10] M. Soffritti, F. Belpoggi, A. Lenzi, C. Maltoni, Results of long-term carcinogenicity studies of chlorine in rats, Ann. NY Acad. Sci. 26 (1997) 189-208.

[11] M.G.C. Baldry, M.S. French, D. Slater, The activity of peracetic acid on sewage indicator bacteria and viruses, Water Sci. Technol. 24 (2) (1991) 353-357.

[12] M.G.C. Baldry, A. Cavadore, M.S. French, G. Massa, L.M. Rodrigues, P.F.T. Schirch, T.L. Threadgold, Effluent disinfection in warm climates with peracetic acid, Water Sci. Technol. 31 (56) (1995) 161-164.

[13] F. Lefevre, J.M. Audic, F. Ferrand, Peracetic acid disinfection of secondary effluents discharged off coastal seawater, Wat. Sci. Technol. 25 (1992) 155-164.

[14] S. Monarca, S.D. Richardson, D. Feretti, M. Grottolo, A.D. Thruston, C. Zani, G. Navazio, P. Ragazzo, I. Zerbini, A. Alberti, Mutagenicity and disinfection by-products in surface drinking water disinfected with peracetic acid, Environ. Toxicol. Chem. 21 (2002) 309-318.

[15] D.M. De Marini, M.J. Plewa, H.E. Brockman, Use of four short-term tests to evaluate the mutagenicity of municipal water, J. Toxicol. Environ. Health 9 (1982) 127-140.

[16] M. Rizzoni, B. Gustavino, C. Ferrari, L.G. Gatti, E.A. Fano, An integrated approach to the assessment of the environmental quality of the Tiber river in the urban area of Rome: a mutagenesis assay (micronucleus test) and a analysis of macrobenthic community structure, Sci. Tot. Environ. 162 (1995) 127-137.

[17] J. Rank, M.H. Nielsen, Evaluation of the Allium anaphasetelophase test in relation to genotoxicity screening of industrial wastewater, Mutat. Res. 312 (1994) 17-24.

[18] T.H. Ma, Tradescantia micronuclei (TRAD-MCN) test for environmental clastogens, in: A.R. Kolber, T.K. Wong, L.D. Grant, R.S. De Woskin, T.J. Huges (Eds.), In vitro toxicity testing of environmental agents, Part A, Plenum Press, New York, 1983, pp. 191-214.

[19] S. Monarca, A. Zanardini, D. Feretti, A. Dalmiglio, E. Falistocco, P. Manica, G. Nardi, Mutagenicity of extracts of lake drinking water treated with different disinfectants in bacterial and plant tests, Water Res. 32 (1998) 2689-2695.

[20] A. Jaylet, P. Deparis, V. Ferrier, S. Grinfeld, R. Siboulet, A new micronucleus test using peripheral blood erythrocytes of the newt Pleurodeles waltl to detect mutagens in fresh-water pollution, Mutat. Res. 164 (1986) 245-257.

[21] A. Jaylet, L. Gauthier, M. Fernandez, Detection of mutagenicity in drinking water using a micronucleus test in newt larvae (Pleurodeles Waltl), Mutagenesis 2 (1987) 211214.

[22] M. Fernandez, L. Gauthier, A. Jaylet, Use of newt larvae for in vivo genotoxicity testing of water: results on 19 compounds evaluated by the micronucleus test, Mutagenesis 4 (1989) 17-26.

[23] T.H. Hutchinson, A.N. Jha, J.M. Mackay, B.M. Elliot, D.R. Dixon, Assessment of developmental effects, cytotoxicity and genotoxicity in the marine polychaete (Platinereis dumerilii) 
exposed to disinfected municipal seawage effluents, Mutat. Res. 399 (1998) 97-108.

[24] R. Scarpato, L. Migliore, R. Barale, The micronucleus assay in Anodonta cygnea for the detection of drinking water mutageniity, Mutat. Res. 245 (1990) 231-237.

[25] J. Mersch, M.N. Beauvais, The micronucleus assay in the zebra mussel, Dreissena polymorpha, to in situ monitor genotoxicity in freshwater environments, Mutat. Res. 393 (1997) 141-149.

[26] C. Bolognesi, E. Landini, P. Roggieri, R. Fabbri, Genotoxicity biomarkers in the assessment of heavy metal effects in mussels: experimental studies, Environ. Mol. Mutagen. 33 (1999) 287-292.

[27] F. Le Curieux, S. Giller, L. Gauthier, F. Erb, D. Marzin, Study of the genotoxic activity of six alogenated acetonitriles, using the SOS chromotest, the Ames-fluctuation test and the newt micronucleus test, Mutat. Res. 341 (1995) 289-302.

[28] J.E. Hose, J.N. Cross, S.G. Smith, D. Diehl, Elevated circulating erythrocyte micronuclei in fishes from contaminated sites of southern California, Mar. Environ. Res. 22 (1987) 167-176.

[29] W.D. Gronlund, S.L. Chan, B.B. McCain, R.C. Clark, M.S. Meyers, J.E. Stein, D.W. Brown, J.T. Landahl, M.M. Krahn, U. Varnasi, Multidisciplinary assesment of pollution at three sites in Long Island Sound, Estuaries 14 (1991) 299-305.

[30] J.B. Hughes, A.T. Herbert, Erythrocyte micronuclei in Winter Flounder (Pseudopleuronectes americanus): result of field surveys during 1980-1988 from Virginia to Nova Scotia and in Long Island Sound, Arch. Environ. Contam. Toxicol. 20 (1991) 474-479.

[31] S. De Flora, L. Viganò, F. D’Agostini, A. Camoirano, M. Bagnasco, C. Bennicelli, F. Melodia, A. Arrillo, Multiple genotoxicity biomarkers in fish exposed in situ to polluted river water, Mutat. Res. 319 (1993) 167-177.

[32] S. Minissi, E. Ciccotti, M. Rizzoni, Micronucleus test in erythrocytes of Barbus plebenius (Teleostei, Pisces) from two natural environments: a bioassay for the in situ detection of mutagens in freshwater, Mutat. Res. 367 (1996) 245-251.

[33] R.N. Hooftman, W.K. de Raat, Induction of nuclear anomalies (micronuclei) in the peripheral blood erythrocytes of the eastern mudminnow Umbra pygmaea by ethyl methansulphonate, Mutat. Res. 104 (1982) 147-152.

[34] R.K. Das, N.K. Nanda, Induction of micronuclei in peripheral erythrocytes of fish Heteropneustes fossilis by mitomycin C and paper mill effluents, Mutat. Res. 175 (1986) 67-71.

[35] N. Schultz, L. Norrgren, J. Gawe, A. Johannisson, O. Medhage, Micronucleus frequency in circulating erythrocytes from rainbow trout (Oncorhynchus mykiss) subject to radiation, an image analysis and flow cytometric study, Comp. Biochem. Physiol. 105 (1993) 207-211.

[36] I.B. Bahari, F.M. Noor, N.M. Daud, Micronucleated erythrocytes as an assay to assess actions by physical and chemical genotoxic agents in Clarias gariepinus, Mutat. Res. 313 (1994) 1-5.

[37] F. Ayllon, E. Garcia-Vasquez, Induction of micronuclei and other nuclear abnormalities in European minnow Phoxinus phoxinus and mollie Poecilia latipinna: an assessment of the fish micronucleus test, Mutat. Res. 467 (2000) 177-186.
[38] K. Al Sabti, Clastogenic effect of five carcinogenic-mutagenic chemicals on the cells of the common carp Cyprinus carpio L., Comp. Biochem. Physiol. 85 (1986) 5-9.

[39] J.C. Nepomuceno, I. Ferrari, M.A. Spanò, A.J. Centeno, Detection of micronuclei in peripheral erythrocytes of Cyprinus carpio exposed to metallic mercury, Environ. Mol. Mutagen. 30 (1997) 293-297.

[40] B. Gustavino, K.A. Scornajenghi, S. Minissi, E. Ciccotti, Micronuclei induced in erythrocytes of Cyprinus carpio (teleostei, Pisces) by X-rays and colchicine, Mutat. Res. 494 (2001) 151-159.

[41] M.L. Landolt, R.M. Kocan. Fish cell cytogenetics: a measure of genotoxic effects of environmental pollutants, in: J.O. Nriagu (Ed.), Aquatic Toxicology, Wiley, New York, 1983, pp. 335-352.

[42] K. Al Sabti, C.D. Metcalfe, Fish micronuclei for assessing genotoxicity in water, Mutat. Res. 343 (1995) 121-135.

[43] K. Belpaeme, K. Delbeke, L. Zhu, M. Kirsh-Volders, Cytogenetic studies of PCB77 on brown trout (Salmo trutta fario) using the micronucleus test and the alkaline comet assay, Mutagenesis 11 (1996) 485-492.

[44] D.E. Nacci, S. Cayula, E. Jackim, Detection of DNA damage in individual cells from marine organisms using the single cell gel assay, Aquat. Toxicol. 35 (1996) 197-210.

[45] C.L. Mitchelmore, J.K. Chipman, Detection of DNA strand breaks in brown trout (Salmo trutta) hepatocytes and blood cells using the single cell gel electrophoresis (Comet) assay, Aqua. Toxicol. 41 (1998) 161-182.

[46] J.C.S. Kleinjans, F.J. van Schooten, Ecogenotoxicology: the evolving field, Environ. Toxicol. Pharmacol. 11 (2002) 173179.

[47] R. Pandragi, M. Petras, S. Ralph, M. Vrzoc, Alkaline single cell gel (Comet) assay and genotoxicity monitoring using bullheads and carp, Environ. Mol. Mutagen. 26 (1995) 345356.

[48] G. Reiffersheid, T. Grummt, Genotoxicity in german surface waters-results of a collaborative study, Water Air Soil Poll. 123 (2000) 67-79.

[49] S. Monarca, C. Zani, C. Rossi, A. Buschini, P. Poli, M. Rizzoni, B. Gustavino, C. Bolognesi, D. Bartoli, E. Ciccarelli, M. Doerr, Evaluation of genotoxicity of disinfected surface water: in vivo assays, Acqua \& Aria 7 (2002) 75-81.

[50] R.R. Tice, E. Agurell, D. Anderson, B. Burlinson, A. Hartmann, H. Kobayashi, Y. Miyamae, E. Rojas, J.-C. Ryu, Y.F. Sasaki, Single cell gel/Comet assay: guidelines for in vitro and in vivo genetic toxicology testing, Environ. Mol. Mutagen. 35 (2000) 206-221.

[51] APHA. Standard Methods for the Examination of Water and Wastewater, 17th ed., American Public Health Association, Washington, DC, 1989.

[52] N.P. Singh, M.T. Mc Coy, R.R. Tice, E.L. Schneider, A simple technique for quantitation of low levels of DNA damage in individual cells, Exp. Cell Res. 175 (1998) 184-191.

[53] A. Buschini, P. Carboni, A. Martino, P. Poli, C. Rossi, Effects of temperature on baseline and genotoxicant-induced DNA damage in haemocytes of Dreissena polymorpha, Mutat. Res. 537 (2003) 81-92. 
[54] S. Huuskonen, T. Räsänen, K. Koponen, P. Lindström-Seppä, Time-course studies of the biotrasformation enzymes in control rainbow trout when adjusting to new habitats, Marine Environ. Res. 39 (1995) 79-83.

[55] C.L. Mitchelmore, J.K. Chipman, DNA strand breakage in aquatic organisms and the potential value of the comet assay in environmental monitoring, Mutat. Res. 399 (1998) 135147.

[56] B. Anitha, N. Chandra, P.M. Gopinath, G. Durairaj, Genotoxicity evaluation of heat shock in gold fish (Carassius auratus), Mutat. Res. 496 (2000) 1-8.

[57] S. Kinoshita, S. Itoi, S. Watanabe, cDNA cloning and characterization of the warm-temperature-acclimationassociated protein Wap65 from carp, Cyprinus carpio, Fish Physiol. Biochem. 24 (2001) 125-134.

[58] E.M. Goolish, M.G. Barron, I.R. Adelman, Thermoacclimatori response of nucleic and protein content of carp muscle tissue: influence of growth rate and relationship to glycine uptake by scales, Can. J. Zool. 62 (1984) 21642170.

[59] M. de la Higuera, A. Garzón, M.C. Hidalgo, J. Peragón, G. Cardenete, J.A. Lupiáñez, Influence of temperature and dietary-protein supplementation either with free or coated lysine on the fractional protein-turnover rates in the white muscle of carp, Fish Physiol. Biochem. 18 (1998) 85-95.

[60] J. Blasiak, K. Widera, T. Pertynski, Hyperthermia can differentially modulate the repair of doxorubicin-damaged DNA in normal and cancer cells, Acta Biochim. Polon. 50 (2003) 191-195.

[61] V. Bombail, D. Aw, E. Gordon, J. Batty, Application of the comet and micronucleus assays to butterfish (Pholis gunnellus) erythrocytes from the Firth of Forth, Scotland, Chemosphere 44 (2001) 383-392.

[62] A. Hartmann, H. Fender, G. Speit, Comparative biomonitoring study of workers at a waste disposal site using cytogenetic tests and the Comet (single-cell gel) Assay, Environ. Mol. Mutagen. 32 (1998) 17-24.

[63] F. Van Goethem, D. Lison, M. Kirsch-Volders, Comparative evaluation of the in vitro micronucleous test and the alkaline single cell gel electrophoresis assay for the detection of DNA damaging agents: genotoxic effects of cobalt powder, Mutat. Res. 392 (1997) 31-43.

[64] S. Monarca, M. Rizzoni, B. Gustavino, C. Zani, A. Alberti, D. Feretti, I. Zerbini, Genotoxicity of surface water treated with different disinfectants using plant tests, Environ. Mol. Mutagen. 41 (2003) 353-359. 